\title{
EFEKTIFITAS PENDIDIKAN KESEHATAN METODE AUDIOVISUAL TERHADAP PENGETAHUAN REMAJA PUTRI TENTANG VULVA HYGIENE
}

\author{
Dwi Elka Fitri ${ }^{1)}$, Jamiati ${ }^{2)}$ \\ ${ }^{1,2}$ STIKes Pekanbaru Medical Center \\ Email: nersiwiek@gmail.com
}

Diterima: Desember 2020, Diterbitkan: Desember 2020

\begin{abstract}
ABSTRAK
Pengetahuan remaja putri yang kurang tentang vulva hygiene bisa menjadi salah satu pencetus keputihan, pengetahuan tersebut meliputi perilaku buang air besar (BAB) dan buang air kecil (BAK) yang buruk. Masalah kesehatan reproduksi merupakan masalah vital untuk membangun serta mempertahakan kesehatan wanita, akan tetapi dalam penyelesaiannya tidak dapat diselesaikan dengan upaya kuratif saja, sehingga diutamakan upaya preventif. Pendidikan kesehatan merupakan upaya yang tepat untuk meningkatkan pengetahuan remaja tentang vulva hygiene. Metode audiovisual lebih mudah dipahami dan menarik bagi remaja. Tujuan dari penelitian adalah untuk mengetahui efektifitas pendidikan kesehatan metode audiovisual. Desain penelitian ini yaitu penelitian one group pre dan post test. Pupulasi dari penelitian ini yaitu seluruh remeja puteri di MAN 1 Indragiri Hilir. Teknik pengambilan sampel yang digunakan pada penelitian ini yaitu teknik purposive sampling, dengan besar sampel 32 orang. Hasil dari penelitian ini menunjukan bahwa didapat nilai mean pre test yaitu 83,25 dan nilai mean post test didapatkan yaitu 98,50. Dari hasil penelitian ini dapat disimpulkan bahwa pemberian pendidikan kesehatan melalui metode audio visual efektif dalam meningkatkan pengetahuan remaja putri tentang vulva hygiene di MAN 1 Indragiri Hilir. Hasil penelitian ini diharapkan dapat dijadikan pedoman bagi responden dalam kehidupan sehari-hari khususnya untuk kesehatan organ reproduksi dan responden juga lebih bisa mengenal bahaya jika tidak melakukan vulva hygiene dengan benar. Bagi tenaga kesehatan, diharapkan untuk selanjutnya dapat menggunakan media audiovisual dalam pelaksanaan pendidikan kesehatan.
\end{abstract}

Kata Kunci : Pendidikan Kesehatan, Pengetahuan, vulva hygiene, media audiovisual.

\section{ABSTRACT}

The lack of knowledge of young women about vulva hygiene can be one of the triggers for vaginal discharge problems, this knowledge includes bad defecation (BAB) and urination (BAK) behavior. Reproductive health problems are a vital problem for building and maintaining women's health, however, the solution cannot be solved by curative efforts alone, so preventive efforts are prioritized. Health education is the right effort to increase adolescent knowledge about vulva hygiene. Audiovisual methods are easier to understand and attractive to adolescents. The purpose of this study was to determine the effectiveness of audiovisual health education methods. The research design was one group pre and post test. The pupulations of this research are all girls in MAN 1 Indragiri Hilir. The sampling technique used in this study was purposive sampling technique, with a sample size of 32 people. The results of this study indicate that the mean pre test is 83.25 and the mean post test is 98.50. From the results of this study it can be concluded that the provision of health education through audio visual methods is effective in increasing the knowledge of young women about vulva hygiene at MAN 1 Indragiri Hilir. The results of this study are expected to be used as a guideline for respondents in their daily life, especially for the health of their reproductive organs, and that respondents will also be more familiar with the dangers of not 
performing vulva hygiene properly. For health workers, it is hoped that they can use audiovisual media in the implementation of health education.

Keywords: health education, knowledge, vulva hygiene, audiovisual media.

\section{PENDAHULUAN}

Menurut World Health Organization (WHO) remaja adalah usia dari 12 sampai 24 tahun. Menurut Depkes RI remaja adalah antara usia 10 sampai 19 tahun dan belum menikah. Menurut BKKBN adalah 10 sampai 19 tahun. Remaja adalah proses seseorang mengalami perkembangan semua aspek dari masa kanak-kanak menuju masa dewasa. Masa peralihan dari kanak-kanak menuju dewasa disebut juga dengan masa pubertas. Masa pubertas adalah masa dimana remaja mengalami kematangan organ reproduksi dan seksual seksual yang sudah mulai berfungsi (Sarwono, 2011).

Masa remaja adalah masa dimana ditandai dengan adanya perubahan fisik, esmosi dan psikis. Masa remaja yakni antara 10-19 tahun, adalah suatu periode masa pematangan organ reproduksi manusia sehingga pada masa ini menjadi masa yang sangat penting dalam menjaga kesehatan reproduks. Kesehatan reproduksi merupakan komponen kesehatan secara umum. Kesehatan reproduksi perlu mendapatkan perhatian khusus apalagi di kalangan remaja terutama perempuan (Mumpuni dan Andang, 2013).

Menurut World Health Organization (WHO) kesehatan reproduksi remaja adalah suatu kondisi sehat yang menyangkut pada sistem reproduksi serta fungsi yang dimiliki oleh seorang remaja. Sehat di sini bukan berarti bebas dari penyakit ataupun kecacatan namun juga harus sehat mental serta sosio kultural.

Berdasarkan data dari Badan Kependudukan dan Keluarga Berencana Nasional didapatkan bahwa pengetahuan remaja putri mengenai kesehatan reproduksi masih sangat rendah. Selain itu, kondisi cuaca di Indonesia yang lembab dapat menjadi faktor penyebab banyaknya wanita Indonesia yang mengalami keputihan (Anugroho dan Wulandari, 2011).

Keputihan merupakan cairan yang berlebihan yang keluar dari vagina. Keputihan bisa bersifat fisiologis namun bisa bersifat patologis. Keputihan fisiologis biasanya terjadi pada masa subur, juga baik sebelum ataupun sesudah menstruasi. Keputihan tidak mengenal batasan umur. Berapapun umur seorang wanita, bisa terkena keputihan (Rozi, 2013).

Keputihan yang abnormal dapat disebabkan oleh infeksi/peradangan yang terjadi karena mencuci vagina dengan air yang tidak bersih, pemeriksaan dalam yang tidak benar, pemakaian cairan pembersih pada vagina yang berlebihan, pemeriksaan yang tidak higienis, dan adanya benda asing didalam vagina (Kusmiran, 2012).

Masalah pada organ reproduksi ini timbul akibat dari perilaku hygiene yang kurang tepat atau tidak benar. Wanita seringkali membersihkan area kewanitaan dengan cara yang salah ataupun membersihkan dengan bahan kimia yang berlebihan. Hal tersebut dapat menyebabkan keseimbangan mikroflora dan $\mathrm{pH}$ vagina menjadi terganggu, sehingga menjadi rentan terhadap infeksi (Manuaba, 2009).

Pengetahuan remaja putri yang kurang tentang vulva hygiene bisa menjadi salah satu pencetus keputihan, pengetahuan tersebut meliputi perilaku buang air besar (BAB) dan buang air kecil (BAK) yang 
buruk misalnya membersihkan dengan air yang tidak bersih, salah arah saat membersihkan, memakai antiseptic, serta pembilas yang berlebihan, memakai celana dalam yang tidak menyerap keringat, ketat, jarang mengganti celana dalam dan jarang mengganti pembalut (Ratna, 2010).

Vulva hygiene merupakan perilaku memelihara alat kelamin bagian luar (vulva) untuk mempertahankan kebersihan serta kesehatan alat kelamin, dan untuk mencegah terjadinya infeksi. Perilaku tersebut misalnya melakukan cebok dari arah vagina ke arah anus menggunakan air bersih, tanpa memakai antiseptic dan sabun secara berlebihan, mengeringkannya dengan handuk kering atau tisu kering, mencuci tangan sebelum membersihkan daerah kewanitaan (Darma, 2017).

Pendidikan kesehatan merupakan istilah yang diterapkan pada penggunaan proses pendidikan secara terencana untuk mencapai tujuan kesehatan yang mencangkup beberapa kombinasi dan kesepakatan belajar atau aplikasi pendidikan didalam bidang kesehatan (Notoatmodjo, 2013). Manfaat pendidikan kesehatan adalah menjadikan kesehatan sebagai sesuatu yang bernilai dimasyarakat, menolong individu agar mampu secara mandiri atau kelompok mengadakan kegiatan untuk mencapai tujuan hidup sehat, mendorong pengembangan dan menggunakan secara tepat dan baik sarana pelayanan kesehatan yang ada (Herawati,2001)

Pendidikan kesehatan dapat dilakukan dengan cara individu maupun kelompok dengan menggunakan media audiovisual, media cetak seperti leaflet, poster, atau spanduk dan media massa yang dapat berupa media cetak seperti koran, majalah, maupun media elektronik seperti radio dan televisi (Widodo, 2004).

Media audiovisual dapat memberikan stimulus terhadap pendengaran dan penglihatan, sehingga hasil yang diperolah lebih maksimal. Hasil tersebut bisa tercapai karena adanya pancaindera yang paling banyak menyalurkan pengetahuan ke otak adalah mata (kurang lebih $75 \%$ sampai $87 \%$ ), sedangkan $13 \%$ sampai $25 \%$ pengetahuan diperoleh atau disalurkan melalui indera yang lain (Maulana, 2009). Berdasarkan penelitian yang di lakukan oleh Saiful Rozi (2018) didapatkan hasil bahwa ada pengaruh pendidikan kesehatan dengan metode audiovisual terhadap pengetahuan vulva hygiene saat menstruasi.

Dari hasil wawancara peneliti mendapatkan data siswa di MAN 1 Indragiri Hilir, hasil wawancara dengan 10 siswa, mereka tidak ada yang mengetahui tentang Vulva Hygiene, 10 siswa mengatakan bahwa pernah mengalami keputihan, 5 siswa mengatakan 3 kali sehari mengganti celana dalam, 4 siswa mengatakan 2 kali sehari mengganti celana dalam, 1 siswa mengatakan hanya 1 kali sehari mengganti celana dalamnya. 9 siswa mengatakan mengalami gatal-gatal pada organ genitalia. 3 siswa mengatakan membersihkan organ reproduksi mengguankan sabun.

Berdasarkan fennomena diatas, maka peneliti tertarik melakukan penelitian untuk mengetahui Efektifitas Pendidikan kesehatan metode audiovisual terhadap pengetahuan remaja puteri tentang vulva higiene.

\section{METODOLOGI PENELITIAN}

Penelitian ini merupakan penelitian kuantitatif Quasy Eksperiment dengan mengunakan desain penelitian one group pre dan post test. Populasi dari penelitian ini yaitu seluruh remeja puteri di MAN 1 Indragiri Hilir. Teknik pengambilan 
sampel yang digunakan pada penelitian ini yaitu teknik purposive sampling, dengan besar sampel sebanyak 32 orang.

Sebelum kuesioner dibagikan, terlebih dahulu peneliti melakukan uji validitas dan reliabilitas di MA Nurul Wathan Pasar Kembang. Uji validitas dilakukan pada 20 responden. Hasil uji validitas kuesioner Pengetahuan didapatkan hasil 25 pertanyaan valid.

Analisis data dalam penelitian ini yaitu analisis univariat dan bivariate. Analisis univariat dilakukan untuk melihat distribus frekuensi karakteristik responden dan distribusi frekuensi pengetahuan remaja puteri. Sedangkan analisis bivariate, dilakukan dengan uji paired sample T test untuk melihat bagaimana efektifitas pendidikan kesehatan menggunakan media audiovisual terhadap pengetahuan remaja puteri tentang vulva hygiene.

\section{HASIL DAN PEMBAHASAN \\ Hasil}

1. Analisis Univariat

Karakteristik Responden Berdasarkan Usia

Tabel 1

Distribusi frekuensi usia responden di MAN 1 Indragiri Hilir

\begin{tabular}{cccc}
\hline No & Usia & Frekuensi & $\begin{array}{c}\text { Persentase } \\
(\%)\end{array}$ \\
\hline 1 & 15 tahun & 9 & $28 \%$ \\
\hline 2 & 16 tahun & 20 & $63 \%$ \\
\hline 3 & 17 tahun & 3 & $9 \%$ \\
\hline & Total & $\mathbf{3 2}$ & $\mathbf{1 0 0}$ \\
\hline
\end{tabular}

Berdasarkan tabel di atas diketahui bahwa sebagian besar responden berusia 16 tahun yaitu sebanyak 20 orang $(63 \%)$.

Tabel 2

Distribusi Frekuensi Responden

Berdasarkan hasil pre test dan post test pengetahuan tentang vulva hygiene dengan metode audio visual

\begin{tabular}{ccc}
\hline Pengetahuan & Mean & $\begin{array}{c}\text { Std. } \\
\text { Deviation }\end{array}$ \\
\hline Pre Test & 83,25 & 4,892 \\
\hline Post test & 98,50 & 2,477 \\
\hline
\end{tabular}

Berdasarkan tabel 4.3 diatas diketahui bahwa sebelum (pre test) dilakukan pendidikan kesehatan dapatkan hasil pengetahuan tentang vulva hygiene diperoleh nilai mean 83,25 dengan standar deviasi 4,892. Setelah (post test) di lakukan pendidikan kesehatan didapatkan nilai mean 98,50 dengan standar deviasi 2,477 .

\section{Analisa Bivariat}

Tabel 3

Efektifitas pendidikan kesehatan metode audiovisual terhadap pengetahuan remaja

\begin{tabular}{|c|c|c|c|c|c|c|}
\hline & $\mathrm{N}$ & Mean & Min & Max & $\begin{array}{c}\text { Std. } \\
\text { Deviation }\end{array}$ & $\begin{array}{c}\text { Uji } \\
\text { Wilcox } \\
\text { on } \\
\text { Nilai } \\
\text { Sig. }\end{array}$ \\
\hline $\begin{array}{l}\text { Pre } \\
\text { Test }\end{array}$ & 32 & 83,25 & 84 & 100 & 4,590 & \\
\hline $\begin{array}{l}\text { Post } \\
\text { Test }\end{array}$ & 32 & 98,50 & 96 & 100 & 1,366 & $\begin{array}{c}p= \\
0.001\end{array}$ \\
\hline
\end{tabular}

Berdasarkan tabel tersebut di atas dengan uji wilcoxon diketahui bahwa nilai $\mathrm{p}$ value $=0,001$ yang mana lebih kecil dari pada nilai alpha $(\mathrm{p}<0,05)$ dapat disimpulkan bahwa pendidikan kesehatan dengan metode audio visual efektif terhadap pengetahuan remaja putri tentang vulva hygiene di MAN 1 Indragiri Hilir.

\section{Pembahasan}

Berdasarkan penelitian karakteristik umur terhadap 16 responden, di dapatkan sebagian besar siswi MAN 1 Indragiri Hilir berumur 16 tahun sebanyak 20 responden (63\%). Kemudian di susul kelompok umur 15 tahun sebanyak 9 responden $(28 \%)$. Umur 17 tahun sebanyak 3 responden (9 $\%)$. 
Usia seseorang dapat mempengaruhi kemampuan dan pola pokir seseorang untuk menerima informasi yang diberikan. Semakin bertambahnya usia maka kemampuan menerima informasi dan pola pikir seseorang semkain berkembang. Semakin bertambahnya umur, tingkat kematangan dan kekuatan seseorang akan lebih matang dalam berpikir serta bekerja (Wawan \& Dewi, 2011).

Menurut Hasnah (2019) dalam penelitiannya menyebutkan bahwa remaja pertengahan memiliki pengetahuan yang lebih baik dibandingkan remaja awal karena pada remaja pertengahan kemampuan berfikir pada seseorang semakin berkembang.

Semakin bertambah usia seseorang akan semakin berkembang pula daya tangkap dan pola pikir, sehingga pengetahuan yang diperolehnya semakin membaik.Salah satu faktor yang dapat mempengaruhi pengetahuan adalah pendidikan. Pengetahuan sangat erat kaitannya dengan pendidikan, dimana diharapkan seseorang yang berpendidikan tinggi, maka seorang tersebut akan luas juga pengetahuannya. Salah satu upaya untuk meningkatkan pengetahuan seseorang adalah dengan pendidikan.

Pendidikan dapat berupa penyuluhan, karena penyuluhan adalah salah satu jenis layanan yang merupakan bagian terpandu dari bimbingan. Penyuluhan adalah hubungan timbal balik antara individu dengan orang lain yang berusaha untuk mencapai pengertian tentang dirinya sendiri dalam hubungan dengan masalah yang dihadapi pada waktu yang akan datang (Machfoed,2005).

Pendidikan kesehatan merupakan aplikasi atau penerapan pendidikan dalam bidang kesehatan. Secara opearasional pendidikan kesehatan merupakan semua kegiatan untuk memberikan dan meningkatkan pengetahuan, sikap, praktek baik individu, kelompok atau masyarakat dalam memelihara dan meningkatkan kesehatan mereka sendiri (Notoatmodjo, 2012).

Pendidikan kesehatan merupakan proses yang direncanakan dengan sadar untuk menciptakan peluang bagi individuindividu untuk senantiasa belajar memperbaiki kesadaran (literacy) serta meningkatkan pengetahuan dan keterampilannya (life skills) demi kepentingankesehatannya

(Nursalam,2008).

Asumsi peneliti usia seseorang mempengaruhi pengetahuan dan pola pikir seseorang. Bertambahnya umur seseorang maka semakin meningkat untuk menerima informasi dalam segala jenis media tulis, gambar maupun media audio visual

Pernyataan ini diperkuat oleh Kustriyani (2009) dalam Soekidjo (2003), yang menyatakan bahwa pada usia madya individu akan lebih berperan aktif dalam masyarakat dan kehidupan sosial serta akan lebih banyak menggunakan waktu untuk belajar serta mencari informasiinformasi terbaru di luar yang tidak didapatkan selama di dalam kelas. Semakin seseorang menginjak tingkat pendidikan yang lebih tinggi maka pengetahuan yang dimiliki jauh lebih baik dari seseorang yang tingkat pendidikannya masih rendah.

Asumsi peneliti semakin sesorang menginjak tingkat pendidikan yang lebih tinggi maka pengetahuan yang di miliki akan semakin bertambah dan berkembang dari seseorang yang pendidikannya masih rendah. Hasil dari penelitian didapatkan bahwa responden yang berada di di Man 1 Indragiri Hilir sebelum (pretest) diberikan pendidikan kesehatan melalui metode audio visual menunjukkan hasil pengetahuan tentang vulva hygiene dengan nilai mean 83,25 dan pengetahuan sesudah (posttest) diberikan pendidikan kesehatan menunjukkan hasil pengetahuan dengan nilai mean 98,50. Hal tersebut menunjukkan bahwa dengan pendidikan kesehatan metode audiovisual pengetahuan remaja puteri tentang vulva hygiene meningkat. 
Hal ini sejalan dengan penelitian Maria Orience Manek (2014) bahwa skor tingkat pengetahuan remaja putri sebelum diberikan pendidikan kesehatan tingkat pengetahuan remaja putri tentang vulva hygiene yaitu 5.75 dan setelah diberikan pendidikan kesehatan tingkat pengetahuan remaja putri tentang vulva hygiene yaitu 8.33 .

Berdasarkan hasil penelitian di peroleh nilai pre test dan post test pengetahuan remaja putri tentang vulva hygiene pada kelompok audio visual dengan menggunakan uji statistik wilcoxon sign rank yaitu $\mathrm{p}=0.001$ yang berarti hipotesis diterima, atau ada pengaruh pendidikan kesehatan terhadap tingkat pengetahuan remaja putri tentang vulva hygiene.

Pengetahuan responden dipengaruhi beberapa faktor, salah satunya adalah informasi yang didapatkan. Pengetahuan merupakan hasil pengindraan manusia atau hasil tahu seseorang terhadap objek melalui indra yang dimilikinya. Sebagian besar pengetahuan seseorang di peroleh melalui indra pendengaran dan penglihatan, suatu informasi bisa di dapatkan dengan pendidikan kesehatan (Notoadmojo, 2005).

Pendidikan kesehatan pada hakikatnya merupakan suatu kegiatan atau usaha untuk menyampaikan pesan kesehatan kepada masyarakat, kelompok atau individu. Dengan harapan agar dengan adanya pesan tersebut mereka dapat memperoleh pengetahuan tentang kesehatan atau lebih baik dan pengetahuan tersebut dapat berpengaruh terhadap perilakunya.

Menurut notoadmodjo

pendidikan kesehatan adalah suatu penerapan konsep pendidikan dibidang kesehatan. Konsep dari pendidikan kesehatan itu adalah pendidikan yang diaplikasikan pada bidang kesehatan dimana didalamnya terdapat proses belajar. Proses belajar memiliki tiga persoalan pokok, yaitu persoalan masukan (input) proses dan persoalan (output).

Berdasarkan hasil penelitian yang dilakukan oleh Wardana (2010), hasil penelitian menunujukan bahwa dengan memberikan penyuluhan dapat memberikan pengaruh yang signifikan terhadap tingkat pengetahuan tentang remaja kesehatan reproduksi perempuan. Hasil penelitian ini menunjukan bahwa terjadinya peningkatan nilai rata-rata pada pengetahuan remaja putri tentang vulva hygiene yaitu setelah mendapatkan pendidikan kesehatan berupa audio visual perbedaan sangat jauh berbeda.

Hal ini juga didukung oleh pepatah Cina kuno dikutip dalam penelitian Ernawati (2012) yang mengatakan bahwa " saya mendengar dan saya lupa, saya melihat dan saya ingat, saya melakukan dan saya mengerti". Dengan demikian peneliti berpendapat bahwa dengan memberikan pendidikan kesehatan terhadap pengetahuan remaja putri berupa penyuluhan, diskusi dan simulasi dapat meningkatkan pengetahuan seseorang terhadap sebuah objek.

Pendidikan kesehatan erat kaitannya dengan proses belajar mengajar. Kemudian dalam proses belajar mengajar yang harus dibuat semenarik mungkin sehingga dapat meningkatkan minat belajar serta fokus peserta didik. Dale mengatakan media Audio Visual merupakan media pengajaran dan media pendidikan yang mengaktifkan mata dan telinga peserta didik selama proses belajar mengajar berlangsung.

Menurut Marshall Meluhan pengertian media merupakan suatu ekstensi manusia yang memungkinkannya mempengaruhi orang lain yang tidak mengadakan kontak langsung dengan dia. Media Audio Visual berasal dari kata media yang berarti bentuk perantara yang digunakan oleh manusia untuk menyampaikan atau menyebar ide, gagasan, atau pendapat sehingga ide, pendapat atau gagasan yang dikemukakan itu sampai kepada penerima yang dituju.

Asumsi peneliti berdasarkan hasil penelitian ada pengaruh terhadap pengetahuan remaja putri MAN 1 Indragiri Hilir setelah diberikan pendidikan kesehatan dengan metode audiovisual. 


\section{SIMPULAN}

Setelah dilakukan penelitian tentang Efektifitas Pendidikan Kesehatan Terhadap Pengetahuan Remeja Putri Tentang Vulva Hygiene di MAN 1 INHIL dapat disimpulkan bahwa :

1. Didapatkan rata-rata (mean) pengetahuan remaja putri pada di MAN 1 Indragiri Hilir sebelum dilakukan pendidikan kesehatan tentang tentang vulva hygiene 83,25 dengan standar deviasi 4,892. Setelah dilakukan pendidikan kesehatan didapatkan nilai rata-rata (mean) responden adalah 99,50 dengan standar deviasi 1,366.

2. Pendidikan kesehatan dengan media audio visual efektif terhadap pengetahuan remaja putri di MAN 1 Indragiri Hilir tentang vulva hygiene. Hal tersebut dapat terlihat nilai $p$ value $=0,001$ yang mana lebih kecil dari pada nilai alpha $(\mathrm{p}<0,05)$.

\section{UCAPAN TERIMA KASIH}

Penelitian ini dapat terlaksana dengan bantuan berbagai pihak. Oleh karena itu peneliti dengan sepenuh hati menyampaikan rasa terima kasih kepada:

1. Keluarga tercinta

2. Civitas Akademika STIKes PMC

\section{DAFTAR PUSTAKA}

Notoatmodjo. (2010). Metodologi Penelitian Kesehatan. Jakarta: PT. Rineka Cipta.

Notoatmodjo. 2011. Teori dan Pengukuran Sikap dan Perilaku. Jakarta: PT. Rineka Cipta

Notoatmodjo. (2012). Promosi Kesehatan dan Perilaku Kesehatan. Jakarta: PT. Rineka Cipta

Notoatmodjo (2012). Metodelogi Penelitian Kesehatan . Jakarta : PT. Medika Cipta

Agus, dkk. (2013). Kapita elekta Kuesioner Pengetahuan dan Sikap Dalam Penelitian Kesehatan. Jakarta: Selemba Medika.
Departemen Kesehatan RI. (2007). Panduan Promosi Kesehatan di Sekolah. Depkes RI, Jakarta .

Arikunto. (2006). Dikutip oleh Wawan, (2011). Prosedur Penelitian Suatu Pendekatan Praktik. Jakarta: Rineke Cipta.

Nurhidayah, Siti. (2016). Hubungan Tingkat Pengetahuan Remaja Putri

Dengan Tingkat Kecemasan Pada Saat Menarche Di SD Negeri 026 Pekanbaru. Sekolah Tinggi Ilmu Kesehatan Pekanbaru Medical Center.

Rosyida, Desta Ayu Cahya. (2019). Kesehatan Reproduksi Remaja dan Wanita. Yogyakarta: PT PUSTAKA BARU.

Widyastuti. (2009). Kesehatan Reproduksi. Yogyakarta: Fitra Maya

Hidayat,A. A. A. (2007). Riset Keperawatan dan Teknik Penulisan Ilmiah. Jakarta: Salemba Medika.

Hidayat,A. A. A. (2009). Metode Penelitian Keperawatan dan Teknik Analisa Data. Jakarta: Salemba Medika.

Nursalam. (2014). Metode Penelitian Ilmu Keperawatan. Jakarta : Salemba Medika.

Sarwono. (2010). Metode Penelitian Kesehatan: Penuntut Praktis Bagi Permula. Jogyakarta: Mitra Cendikia.

Nursalam. (2008). Konsep \& penerapan metodologi penelitian ilmu keperawatan: pedoman skripsi, tesis dan instrument penelitian keperawatan, Edisi: 1. Jakarta: Salemba Medika.

Wawan A., dan Dewi M. 2011. Teori dan Pengurkuran Pengetahuan, Sikap dan Perilaku Manusia. Yogyakarta: Nuha Medika.

Burn, N., Grove, S. K. (2005). The practice of nursing research : conduct, critique, and utilization. Missouri : Elsevier saunders.

Sari, Rita Purnomo. (2012). Hubungan Pengetahuan dan rerilaku Remaja 
Putri dengan Kejadian Keputihan di Kelas XII SMA Negeri Seunuddon Kabupaten Aceh Utara. http//Rita_Purnomo_Sari-ygojurnal//2012//pdf/. Diakses 20 Januari 2020.

Ubaiybingokil. (2012). pengetahuan tentang keputihan. http//informasiterbaru69.

blogspot.com/2012/03/pengetahuan -tentang-keputihan.html diakses 22 Januari 2020.

Widyastuti. (2009). Kesehatan Reproduksi. Yogyakarta: Fitra Maya

Nursalam, (2013). Metodologi Penelitian Ilmu Keperawatan Edisi 3. Jakarta : Salemba Medika

Proverawati, dan Samiroh, S. (2009). Menarche Menstruasi Pertama Penuh Makna. Yogyakarta: Nuha Medika

Nurhidayah, Siti. (2016). Hubungan Tingkat Pengetahuan Remaja Putri Dengan Tingkat Kecemasan Pada Saat Menarche Di SD Negeri 026 Pekanbaru. Sekolah Tinggi Ilmu Kesehatan Pekanbaru Medical Center.

Suryani, L. (2019). Faktor-Faktor yang Mempengaruhi Perilaku Remaja Putri Tentang Personal Hygiene Pada Saat Menstruasi. Jurnal of Midwifery Science, di akses tanggal 20 januari 2020

Atapukang, F. (2017). Hubungan Tingkat Pengetahuan Remaja Putri Tentang Vulva Hygiene dengan Kejadian Keputihan di SMP Muhammadiyah 1 Yogyakarta. Di akses tanggal 18 Januari 2020

Rofi'ah, S. (2017). Efektifitas Pendidikan Kesehatan Metode Peer Group Terhadap Tingkat Pengetahuan dan Sikap Personal Hygiene Saat Menstruasi. Jurnal Ilmiah Bidan. Di akses tanggal 24 januari 2020

Ayuningtys, Donatalia Novrinta. (2011). Hubungan Antara Pengetahuan dan Perilaku Menjaga Kebersihan Genetalia Eksternal dengan
Kejadian Keputihan Pada Sisiwi SMA Negeri 4 Semarang. Di akses tanggal 27 januari 2020

Rosyida, Desta Ayu Cahya. (2019). Kesehatan Reproduksi Remaja dan Wanita. Yogyakarta: PT PUSTAKA BARU

Notoatmodjo. (2005). Metodologi penelitian kesehatan. Jakarta : PT Rineka Cipta.

Putri, S. (2016). Pengaruh pendidikan kesehatan tentang vulva hygiene Al-Izzah Demak. Jurnal Keperawatan

Wawan A., dan Dewi M. (2010). Teori dan Pengurkuran Pengetahuan, Sikap dan Perilaku Manusia. Yogyakarta: Nuha Medika.

Zakiudin, A. (2016). Perilaku Kebersihan Diri (Personal Hygiene) Santri di Pondok Pesantren Wilayah Kabupaten Brebes akan Terwujud Jika di Dukung dengan Ketersediaan Sarana Prasarana. Jurnal Promosi Kesehatan Indonesia. Di akses tanggal 25 januari 2020 